Nyssen, J., Van den Branden, J., Spalević, V., Frankl, A., Vandevelde, L., Čurović, M., Billi, P., 2014. Twentieth century land resilience in

Montenegro and consequent hydrological response. Land Degradation and

Development, 25: 336-349.

\title{
Twentieth century land resilience in Montenegro and consequent hydrological response
}

Jan Nyssen ${ }^{1, *}$, Jeroen Van den Branden ${ }^{1}$, Velibor Spalević ${ }^{2}$, Amaury Frankl ${ }^{1}$, Lisa Vandevelde ${ }^{1}$, Milic Čurović ${ }^{2}$, Paolo Billi ${ }^{1,3}$

${ }^{1}$ Ghent University, Department of Geography, Ghent, Belgium

${ }^{2}$ Biotechnical Faculty, Forestry Department, Podgorica, Montenegro

${ }^{3}$ University of Ferrara, Department of Earth Sciences, Ferrara, Italy

\begin{abstract}
To study the magnitude of land degradation, desertification or resilience in Montenegro throughout the $20^{\text {th }}$ and early $21^{\text {st }}$ century, we re-photographed the landscapes pictured on 48 historical photographs dating back to periods between 1890 and 1985, and analysed in a semiquantitative way the land use and cover changes that occurred through an expert rating system (six correspondents). Time series of hydrology and population density were analysed for the period since 1948, and compared to the changes observed through repeat photography. Overall, vegetation cover has strongly increased and barren areas occupy less space. The industrialisation that expanded in the 1950 s led to strong urbanisation. Despite steadily increasing population (with the notable exception of the Mountain region), the vegetation cover has increased strongly and everywhere. This denser vegetation has led to higher infiltration of rainfall. Partitioning of infiltration water led on one hand to deep infiltration and better low flows and on the other hand to increased evapotranspiration at the boundary layer, leading to decreased total runoff coefficients. In the Mountain region, runoff coefficients have increased, which may be related to earlier snowmelt. Overall, the findings of this study are in line with observations elsewhere in the former SFR of Yugoslavia that, as a result of erosion control and significant vegetation regrowth, the changes observed over a century point to land resilience and not to desertification.
\end{abstract}

Key words: Discharge, Land degradation, Population growth, Repeat photography, Runoff coefficient

\section{Introduction}

Recent studies discuss (Brandt and Thornes, 1996; Geeson et al., 2002; Hill et al., 2008; Hooke, 2006; Kosmas et al., 1997; Le Houérou, 1989), and sometimes question (Butzer, 2005; Grove and Rackham, 2001), the magnitude of land degradation and desertification in the Mediterranean basin, the human responses, and the linkages with land use and cover (LUC) changes. This is an actual environmental issue, where mostly the strong evidence for trends in desertification/ 
resilience does not go beyond the 40 years of Landsat imagery or the 60 years of aerial photography.

Mediterranean countries are especially vulnerable to desertification, as they have to deal with a highly variable climate and a historical human pressure on the land (Beguería et al., 2008; White et al., 1997). Montenegro, a Balkan country in the Eastern Mediterranean basin (Fig. 1), has seen human activity for thousands of years. In line with the whole Western Balkan region, the period up to the mid 1950s was characterised by great agrarian pressure and resulting accelerated erosion (Zlatić, 2002b; Zlatić and Dragovic, 1998). The nature of human impact on the environment has dramatically changed with industrialisation, which led to rural depopulation and changes in the structure of agricultural production. Arable fields were left uncultivated and turned into shrub- and woodland. Mountain areas were largely abandoned and came under woody vegetation. In recent years, with the economic crisis related to the violent dismembering of the former Socialist Federal Republic (SFR) of Yugoslavia, some marginal lands were cultivated again (Grimes et al., 2005).

\section{< Figure 1 approximately here>}

In the last three decades, the consequences of the human use of the environment have become more visible, but also more studied. Research investigating the consequences of land-use change has generally focused on major issues such as the effects (1) on climate (Kalnay and Cai, 2003; Pielke et al., 2002), (2) on habitat loss and biodiversity (Geist and Lambin, 2006), and (3) on hydrology (e.g., Coppin and Richards, 1990; Descheemaeker et al., 2009; Styczen and Morgan, 1995).

LUC change studies may involve the use of time series of aerial photographs, but most commonly such studies are limited to the last 40 years, when satellite imagery has been available. In order to gain time depth, repeating of historical photographs has become an alternative. Sometimes, repeat photography complements quantitative LUC change studies (Grove and Rackham, 2001; Turner et al., 1998); in rare cases, the historical photographs are used as quantitative data (Hoffman and Todd, 2010; Meire et al., 2011; Nyssen et al., 2009; Nyssen et al., 2008; Webb and Hereford, 2010).

In this paper, we have selected Montenegro as a case study area for LUC changes in the $20^{\text {th }}$ and early $21^{\text {st }}$ century with special focus on (1) the temporal component (is the human impact increasing or decreasing and what are major changes in trend?; are the forests recovering from former - human - pressure, or does the constant stress of the harsh, semi-arid climate prevent resilience?), (2) the spatial distribution of LUC changes in Montenegro (to which degree are the different regions influenced by increasing or decreasing human pressure?), and (3) the hydrological response (are there changes in river discharge and hydrogeomorphology?; to what extent may this be related to observed LUC changes?).

\section{Study area: Montenegro}

\subsection{Physiographic setting}

Montenegro lies within the Dinaric Alps, a range dominated by carbonate rocks, with some other sedimentary and volcanic rocks, particularly in the North. Montenegro's climate is strongly determined by its mountains. Besides the occurrence of important vertical temperature and rainfall gradients, local orographic rain may be important. The Dinaric Alps act as a barrier between Mediterranean and continental air masses, and this results in two major climatic zones in 
Montenegro. In the southern part, the Mediterranean climate prevails, while inland the climate is more continental.

Vegetation distribution is strongly influenced too, by (a) the distance to the Mediterranean Sea (continental or maritime climate), and (b) the altitude (temperate or mountain climate). As Montenegro has a well developed relief, large differences in vegetation occur over short distances (Wraber, 1983).

\subsection{Economic and socio-cultural aspects of Montenegro}

Montenegro is a small republic in South-eastern Europe, part of the Balkan Peninsula, with an area of $13812 \mathrm{~km}^{2}$ and a population of 672180 (Montenegro Statistical Office, 2008). It is an independent state since 2006, when it split away from Serbia. The formation of a specific Montenegrin culture and nation started in the fifteenth century (Radojičić, 2008). The idea of a cultural independency grew stronger in the period from 1697 to 1918, during the reign of the Petrović Njegoš dynasty. Between 1918 and 1941, Montenegro was a part of the Kingdom of Yugoslavia and between 1945 and 1990 it was part of the SFR of Yugoslavia. During the first period, Montenegro experienced complete economic and cultural backwardness, while the second meant more general progress (Radojičić, 2008).

Montenegro on a regular basis has been war-stricken, as the Balkans have been a terrain attractive for foreign interventions that have taken advantage of the presence of mixed ethnic groups which can conflict: the Montenegrin-Ottoman War (1876-1878), the Balkan Wars (1912 and 1913) and the Second World War (1941-1945). Though Montenegro was relatively spared in the recent wars related to the breaking up of Yugoslavia, these had a strong negative impact on the economy.

Wars can result in land abandonment and degradation of the arable land (Hupy and Schaetzl, 2006; Mannion, 2003), but there are also other socio-economic factors that can have an effect on the changes in LUC, for instance the transition from a dominantly agricultural society in 1948 (75.4\% of the population active in the agricultural sector) to an economy based on secondary and tertiary activities in 2003 (5.3\% in agriculture) (Radojičić, 2008). Tourism also grew in importance in the last decades, especially on the coast. As a result of the decline in the agrarian interests, there occurred a strong depopulation of the rural settlements and intensified urbanisation (Radović, 1981). The average population density is about 49 persons $/ \mathrm{km}^{2}$, but one should keep in mind that $60 \%$ is urbanised (United Nations, 2008).

$<$ Figure 2 approximately here>

\subsection{Geographic regions}

Three homogeneous geographic regions are generally distinguished, with common geological, climate and vegetation features:

1. The Montenegrin coast is a narrow strip (max. $15 \mathrm{~km}$ wide) along the Adriatic Sea, with alternating sedimentary and volcanic rocks and karstified limestone and dolomite (Radulovic and Radulovic, 1997). Steep limestone mountains rise rapidly to an average height of $800 \mathrm{~m}$. The Kotor ria is a clear example of such steep slopes (Fig. 2). This results locally to strong orographic rain; for instance, Crkvice (940 m a.s.1.), a village above the Kotor Bay receives $4600 \mathrm{~mm} / \mathrm{y}$ (HMSM, 2010), one of the highest amounts in Europe. The Coastal region is dominated by sclerophyllous Mediterranean evergreen shrubs, with small leaves to reduce transpiration. As the area has been strongly grazed through centuries, there is a predominance of species with spiny leaves (Wraber, 1983). The Coastal area has suffered recently from an intensified tourist industry. 
Cities like Bar or Budva are crowded and building occurs on the steep hillslopes, which has had an impact on agriculture, the availability of groundwater and the environment in general.

2. Central Montenegro consists of a karstic plateau on thick Mesozoic limestone. The Innerland region comprises important polja (plural of polje, a large karstic depression), particularly the Nikšić polje $\left(66.5 \mathrm{~km}^{2}\right)$, the Bjelopavlići plain $\left(72 \mathrm{~km}^{2}\right)$ and the Zeta plain $\left(250 \mathrm{~km}^{2}\right)$ (Radojičić, 2008), the bottoms of which are filled with Quaternary materials (Veldkamp and Gams, 1978). The Mediterranean climate in this region comprises hot, dry summers and mild and wet winters. For instance, Podgorica (previously known as Titograd), at $44 \mathrm{~m}$ a.s.l., records the highest average annual temperature $\left(15.2^{\circ} \mathrm{C}\right)$ of the country. The average maximum temperature during summer is over $30{ }^{\circ} \mathrm{C}$ and the annual precipitation of $1600 \mathrm{~mm}$ falls mostly during autumn and winter. Typical are the absence of surface waters, such as rivulets or lakes, and there is a great amount of caves, hence a complex hydrological situation. This results in a harsh landscape with insufficient soil formation. There is Mediterranean forest, with sclerophyllous characteristics, but these are less distinct than in the Coastal zone. Typical are hornbeam and oak forests with autumn moor grass (Wraber, 1983). Plants and animals are scarce and the only fertile pieces of land are the polja. The plateau is cut through by a large depression, composed of plains and polja, which is economically the most important part of the country. The two largest cities of Montenegro, Podgorica and Nikšić, are also situated here, and are well connected by road and rail. Furthermore, this depression is highly fertile, and thus used for cropping; the nearby slopes are grown with vines. Through the depression, the Zeta and the lower Morača flow into Skadar Lake.

3. The third region is the north of Montenegro, a high mountain area with plateaus covered by meadows and forests. These plateaus are incised by canyons of the upper streams of the Morača and Tara. The rivers Piva and Komarnica flow through a less hilly terrain, which consists of older, Palaeozoic rock formations. This results in less incised river valleys, where some important urban centres are situated, such as Andrijeva, Pljevlja or Berane. The core of this region is the Durmitor mountain range, which contains the highest peak of Montenegro, the Bobotov Kuk (2523 $\mathrm{m}$ a.s.1.). The inland continental climate is characterized by cold winters and warm humid summers. Plevlja, at $784 \mathrm{~m}$ a.s.l., records an average annual temperature of $8.8^{\circ} \mathrm{C}$ only and an average annual precipitation of $1100 \mathrm{~mm}$ (HMSM, 2010), more or less equally distributed over the seasons. In the highest mountains, annual snowfall is over 2 metres (COWI, 2010). Here occur subalpine deciduous forests; beeches have a stocky character, because of the harsh, cold conditions. On the higher grounds and near the valleys of the Lim and Čehotina the pine forests are well represented. The highest areas are covered by alpine herbs (Wraber, 1983).

\subsection{Hydrography}

Given the strong dominance of karst and the very active neotectonics, the hydrological network in Montenegro is complex. As rain water disappears quickly into limestone bedrock, the drainage density is low. The Coastal area has one large river, the Bojana, that drains Lake Skadar to the Adriatic Sea. This lake came into existence by the closure of an inlet of the Adriatic Sea by dune building (Ager, 1980). Skadar Lake is between 350 and $550 \mathrm{~km}^{2}$ large, depending on the height of the water level, which is on average at $6 \mathrm{~m}$ a.s.1. (van Welden et al., 2008), and has a unique ecosystem with important riparian wetlands. The Drim River, a tributary of the Bojana River originating from Albania, can obstruct the natural discharge of Lake Skadar during extreme flash floods, and backwater flow into Bojana River may occur (Prohaska and Isailovic, 2004). 
In central Montenegro, the upper Zeta flows through the Nikšić polje and has a rather small average discharge $\left(Q_{\text {mean }}=18 \mathrm{~m}^{3} / \mathrm{s}\right.$ at Duklov Most) (Bošković and Bajković, 2002). This river enters into a ponor near a mountain range at the south side of the polje and rises in a resurgence $550 \mathrm{~m}$ lower to form the lower Zeta. Both rivers are connected through an underground karst stream. At Danilovgrad, the lower Zeta has a $Q_{\text {mean }}$ of $78 \mathrm{~m}^{3} / \mathrm{s}$ (Bošković and Bajković, 2002). This meandering river (Online Supplementary Data, Annex 2, photo-couple 15) flows through the Bjelopavlići plain into the Morača near Dukla (Podgorica).

The upper Morača is incised in the thick limestone plateau of central Montenegro and forms a 38 $\mathrm{km}$ long canyon (Radojičić, 2008). In Podgorica, the lower Morača has a Qmean of $162 \mathrm{~m}^{3} / \mathrm{s}$ (Bošković and Bajković, 2002), after receiving the Zeta.

The north of Montenegro belongs to the Black Sea basin. The rivers Lim, Ibar, Ćehotina, Tara and Piva flow towards the Danube. The Tara and Piva form canyons in the Mesozoic Limestone of central Montenegro. The Cehotina, Tara and Piva at the north-east of Montenegro stream through softer Paleozoic rocks and, as already mentioned, form broader valley bottoms where human occupation is concentrated. The typical $Q_{\text {mean }}$ of each of these rivers is about $50 \mathrm{~m}^{3} / \mathrm{s}$ (Bošković and Bajković, 2002; Spalević, 2011).

\section{Research methodology}

\subsection{Analysis of time-lapsed terrestrial photographs}

\subsubsection{Historical photograph selection}

Forty-eight historical photographs, dating back to periods between 1890 and 1985, could be collected from various sources on the internet, from one book (Wyon and Prance, 1903), and from the National Museum of Montenegro in Cetinje (Online Supplementary Data, Annex 1). Criteria used when selecting the photographs were that they had an acceptable quality and resolution, and represented areas which could be relocated.

\subsubsection{Repeat photography}

To relocate historical photographs in Montenegro we used indications on some of the photographs, knowledge of the country, screening of the landscape using Google Earth, and memories of elderly local residents. The approximate original viewpoint was retrieved through identification of unique features such as mountain peaks, drainage ways, infrastructure and their relative position. The exact camera position and orientation were obtained by lining up near and distant objects in a triangulation system. Eventually, a photograph was made, which enclosed the same landscape as depicted on the historical photograph. All repeated photographs have been included in the Online Supplementary Data, Annex 2. However, due to the absence of identifiable objects, some 30 historical photographs available could not be repeated and were not included in the study.

\subsubsection{Land use and land cover classes}

Changes that have occurred since the historical photographs were taken are expressed as changes in LUC. Both concepts are quite distinct, though more or less related. Land cover is determined by direct visual observation or through use of electromagnetic radiation in satellite imagery (Fisher et al., 2005). Land use is a socio-economic interpretation of the activities which people develop on the surface, such as cropland or grazing land. A many-to-many relation exists between both concepts (sensu Comber et al., 2007; Gorte, 1998): grass (land cover) can be used as pasture, a park or a sports field (land use). A residential neighbourhood (land use) comprises trees, roads and buildings (land cover). In this study, we derived historical land use from the 
represented land cover on an old photograph, in which we made the most rational assessment (see next section).

The following land use types were determined in the field:

- $\quad$ Forest: wooded areas with at least 50\% canopy cover, comprising single stemmed and woody plants greater than $5 \mathrm{~m}$ high;

- $\quad$ Scrubland: areas dominated by xerophytic shrubs, generally close to the ground;

- $\quad$ Meadows: agricultural land used for grazing of livestock, usually quite extensive;

- $\quad$ Barren land: non-vegetated areas such as bare soil or rock, excluding agricultural fields. Less than one-third of the area has vegetation cover;

- $\quad$ Farmland: land used for the production of food. This includes areas under crop, orchards and fallow;

- Housing or other infrastructure: areas dominated by the permanent presence of people and their structures. Included in this category are houses, industrial facilities and roads.

\subsubsection{Analysis of the sets of matched time-lapsed photographs}

An expert evaluation was done on 48 photo-couples (two of which were separated into two parts each) by six physical and landscape geographers from the Universities of Ghent and Ferrara who are familiar with judging landscape changes (Paolo Billi, Amaury Frankl, Koen Gillijns, Lisa Vandevelde, Jeroen Van den Branden and Jan Nyssen). The recent photographs were turned into black and white to ensure a more objective comparison.

The land use distribution was estimated as percentages of the complete landscape pictured on the photograph. The correspondents corrected the over-representation of the foreground and the under-representation of the mountainsides by estimating the true surface area. Further, the correspondents provided additional comments regarding topics including vegetation cover, land management, human pressure, effects on runoff, soil erosion and hydrogeomorphology, which were useful to understand the landscape changes.

To have the most precise average value for every land use type as interpreted by the participants, a correction was done for outliers, in which the land use distribution values were taken as determined for each photo-couple by the four most reliable correspondents. For every land use distribution value (percent), the average was calculated of the interpretations by the six correspondents. As there were six land use classes and an old and a new photograph, this resulted in 12 averages. Next, the deviation $D$ between the land use distribution estimate and the average was calculated for every correspondent as:

$D=\Sigma D_{i j}$

with

$$
D_{i j}=\left|x_{i j}-\bar{x}_{i j}\right|
$$

and

$x_{i j}=$ the share of a particular land use class as estimated by the correspondent,

$\bar{x}_{i j}=$ the average of shares estimated by all correspondents,

$i_{1}=$ forest,$i_{2}=$ shrubland, $\ldots, i_{6}=$ infrastructure, and

$j_{1}=$ old photograph and $j_{2}=$ new photograph. 
The obtained total deviation is an expression of the difference between the correspondent's interpretation of the land use distribution for the photo-couple at the two epochs and the average land use distributions estimated by all the correspondents. Eventually, for every photo-couple, the two interpretations with the largest deviation were not included in the calculation of the average interpretation.

\subsection{Hydrological response}

\subsubsection{Hydrological data}

The hydrological time series of the rivers Zeta and Morača have been studied in detail. One hydrological station was used for the Zeta: Danilovgrad. Three stations were used for the Morača: Zlatica and Pernica on the upper Morača and Podgorica, just downstream of the confluence of Zeta and Morača.

The topographic basin of every hydrological station was determined by distinguishing the water divides. As Morača and Zeta flow through a strong karstic area, there are poorly known underground rivers and aquifers which follow their own pattern, independently from the surface. Hence, the area of the topographic basins can merely serve as an approximation of the size of the hydrological basin.

Hydrological data analysed included the minimum $\left(\mathrm{Q}_{\min }\right)$, the average $\left(\mathrm{Q}_{\text {mean }}\right)$ and the maximum daily discharges $\left(\mathrm{Q}_{\max }\right)$, on yearly basis. $\mathrm{Q}_{\min }$ and $\mathrm{Q}_{\max }$ stand for the average discharge of the river during the day with the least and highest discharge. These different discharges strongly vary: typically $\mathrm{Q}_{\min }$ is an order of magnitude smaller than $\mathrm{Q}_{\text {mean }}$ and $\mathrm{Q}_{\max }$ an order of magnitude larger.

The discharges measured at Podgorica were checked for consistency, which was rendered possible because this station measures discharges that are also measured in Danilovgrad (Zeta) and Zlatica (Morača) stations, which are some 10-20 km upstream of the confluence.

\subsubsection{Meteorological data}

Monthly rainfall data of 11 meteorological stations (HMSM, 2010) were used to calculate the amount of precipitation in the basins of the Morača and Zeta. Data gaps were filled by interpolation, using values recorded at other meteorological stations through the inverse distance weighting method (Teegavarapu and Chandramouli, 2005).

\subsubsection{Runoff coefficients}

Assuming that relief, climate, soil and rock type have not changed much over a short time span, we expect that LUC changes were the major factor leading to changes in runoff and river discharge. Runoff coefficients (RC) were calculated for various stations in the Morača and Zeta basins (Table 1) as a coefficient of runoff depth $(\mathrm{mm} / \mathrm{month}$, river discharge divided by catchment area) and precipitation depth in its basin.

< Table 1 approximately here>

In the Zeta basin there is only one meteorological station, Danilovgrad, which is near the outlet, at the lowest position and receiving less than average catchment rainfall. The discharges measured at the hydrological stations of Pernica and Zlatica were matched against the weighted average of five and nine meteorological stations by dividing their basins in Thiessen polygons (Isaaks and Srivastava, 1989). Given the similarity in observation period (Table 1), rainfall data 
of Podgorica town were matched with river discharge there. The other meteorological stations that cover the basin all have recording periods that are much shorter than the discharge series of the Morača at Podgorica, and were not used in the analysis.

Two coefficients were calculated for every year:

- Low flow coefficient (LFC): the minimum daily discharge $\left(\mathrm{Q}_{\min }\right.$, occurring in summer and lasting for long periods) compared to the average precipitation of the precedent months January until June, deemed to be the period when the aquifers are filled, which deliver the summer low flows.

- Runoff coefficient $(\mathrm{RC})$ : the average yearly discharge $\left(\mathrm{Q}_{\text {mean }}\right)$ compared to the total precipitation in that year.

No RC was calculated for the maximum daily discharge as this cannot be compared to the available meteorological data that are established on monthly basis.

\subsubsection{Recurrence intervals}

To analyse possible changes over time in flood flows, their frequency, expressed in terms of recurrence interval (tr) was determined. For periods, before and after 1980, the flood frequency curve was obtained by using the highest annual daily discharge:

$\operatorname{tr}=(\mathrm{N}+1) / \mathrm{m} \quad($ Bras, 1990$)$

where: $\mathrm{N}$ is the number of ranked flood values, and $\mathrm{m}$ is the rank of a specific value. The recurrence time tr for a given flood flow corresponds to the time interval that is statistically expected to occur between two floods of that same discharge. The flood frequency curves for high, low and average discharges showed however little change between the early (1948-1980) and late part (1980-2004) of the study period: these were not further considered.

\subsection{Population dynamics}

As basic socio-economic data, the changes in population of every municipality (Montenegro Statistical Office, 2008) were analysed for the period 1948 - 2003. This was complemented with additional data found in the literature.

Such formal data have however only been established at the scale of municipalities which have the size of districts, and do not represent population moves from rural areas to district towns. Occasionally, repeat photographs show increases and decreases in habitat density.

\section{Results}

\subsection{Historical and recent photographs}

The land-use changes in Montenegro (Fig. 3) show that on average the area covered by dense vegetation increased from about $35 \%$ in the early $20^{\text {th }}$ century, to $56 \%$ in 2009 . This increase took place in the second half of the $20^{\text {th }}$ century. The share of agricultural land, represented by meadow and farmland stayed constant, although the agricultural character of the areas that were photographed in 1925-1931 distorts the result. The decrease in barren areas is quite remarkable, from 50\% in 1890-1970 (except for the already mentioned period 1925-1931) to 23\% in 2009. The share of infrastructure is increasing, although it remains a marginal land use type in the photographs that were used.

$<$ Fig. 3 approximately here> 
Some different tendencies appear when considering the Coastal, Innerland and Mountain regions separately. The area occupied by forest and shrubland has clearly increased in the Coastal region (Fig. 4a). Although only eleven historical photographs have been used, the trend is quite obvious: barren land decreased from $54 \%$ in the early $20^{\text {th }}$ century to $39 \%$ in 2009 . Agricultural land, represented by meadow and farmland, decreased, but this type of land use appears on so few photographs that it is not possible to make hard conclusions for meadow or farmland.

Two of the earliest photographs came from Kotor, covering the same area as the photographs from 1960-1985. Between 1890-1910 and 2009, low semi-natural vegetation cover has changed into forest and dense shrubland (Fig. 2). Most likely, the increase took place before 1960-1985, because the land-use changes between that period and the current situation are only minor.

<Figure 4 approximately here>

The Innerland region consists of two different geomorphic subregions, a limestone, karstic plateau, which is cut through by a depression. These subregions have been grouped because there is not enough photographic material available to obtain a clear view of the changes that agricultural lands in plains and polja went through. For instance, the photographs of Spuž, Nikšić or Rijeka Crnojevića do not display the fertile plain, but rather the surrounding hills and mountains. The Innerland region is quite suitable for agriculture; however the agricultural areas in the Bjelopavlići and Zeta plains are underrepresented in the set of historical photographs, probably for sake of absence of scenery.

For this Innerland region (Fig. 4b), only two photographs of the intermediate period, between 1910 and 2009, could be retrieved (Online Supplementary Data, Annex 2, photo-couples 36 in Ostrog (1931) and 43 in Rijeka Crnojevića (1969)) so that this period could not be incorporated in the quantitative analysis of the time series. Yet, an incidental time series exists for this region (the hills around Skadar Lake in 1910, 1969 and 2009, Fig. 5), which shows increasing vegetation cover and density, particularly after 1969. Overall, there was an important increase in forest and shrubland between 1910 and 2009 (Fig. 4b), and a strong decrease of barren areas, from 49\% to $23 \%$.

< Figure 5 approximately here>

In the Mountain region (Fig. 4c), given the small number of historical photographs spread over an important vertical interval (between 320 and $2007 \mathrm{~m}$ a.s.1.), the time period was taken wide enough (1903-1929) to incorporate all eight historical photographs, so that we have an overall view of LUC in the early $20^{\text {th }}$ century. In this region, the agricultural lands that mostly occupy narrow valley bottoms are well represented on the photographs. The forested area has increased, barren land decreased from $9 \%$ to $3 \%$ and agricultural land (farmland and meadows) from 52\% to $40 \%$ (Fig. 6).

$<$ Figure 6 approximately here>

Besides the changes that occurred during the $20^{\text {th }}$ century inside the regions, there are also some general regional differences. Particularly, the Mountain region has completely different characteristics as compared to the Innerland and the Coastal regions. Although the share of woody vegetation is nearly the same (around 50\%) for the three regions, there is nearly no barren land can be found in the Mountain area. In 2009, 39\% of the Coastal region was classified as 
barren and $23 \%$ in the Innerland region. This is only $3 \%$ in the Mountain area, where rocky soils and steep slopes are occupied by meadows. Within the woody vegetation, the share between shrubland and forest is also rather different between the regions. In 2009, in the Coastal region, $50 \%$ of the woody vegetation is shrubland, against $39 \%$ in the Innerland region and only $14 \%$ in the Mountain region.

\subsection{Hydrological response}

\subsubsection{Consistency of discharge data}

When comparing the sum of the discharges measured on the Zeta at Danilovgrad and on the Morača at Zlatica to the discharges measured at Podgorica, we found that the average $\left(Q_{\text {mean }}\right)$ and the maximum discharges $\left(\mathrm{Q}_{\max }\right)$ fit well. The discharges measured at Podgorica are larger than the sum of the discharges measured at Danilovgrad and Zlatica, because the catchment of Podgorica is larger than the sum of the catchments of Danilovgrad and Zlatica (Table 1). The gap between both $\mathrm{Q}_{\min }$ graphs (Podgorica vs. Danilovgrad + Zlatica) is larger than for $\mathrm{Q}_{\operatorname{mean}}$ and $\mathrm{Q}_{\max }$.

\subsubsection{Runoff coefficients}

The trends in rainfall and RC at Pernica, Zlatica, Danilovgrad and Podgorica may be represented by linear trend lines. In the long-term, yearly rainfall at Podgorica is remarkably stable since the 1950s, whereas that of Danilovgrad decreases slowly but stays well above $2000 \mathrm{~mm} / \mathrm{y}$ (Fig. 7a). Weighted average rainfall since the early 1980s in the sub-basins of the upper Morača shows stability at Pernica and decrease at the more downstream Zlatica. Due to the mountainous character of the study area, and the fact that rainfall was recorded in valley bottoms, it is deemed that average rainfall over the catchments is greater than the measurement results.

$<$ Figure 7 approximately here>

The average RC (Fig. 7b), a ratio between average discharge and average precipitation, often exceeds $100 \%$, which is, as already mentioned, related to (1) the karstic nature of the terrain (Zogovic 1990), and (2) systematic underestimation of rainfall, as the meteorological stations are mostly located in valley bottoms. What we study here are the changes in RC.

The temporal changes in RC show an important variability. The low flow coefficient LFC (Fig. 7c) increased strongly on the upper Morača after 1980 (slope of the trendline is 0.004 in Pernica and 0.005 in Zlatica). The yearly RC is also increasing for both basins (0.006 in Pernica and 0.015 in Zlatica). The LFC and RC for the Zeta River, measured at Danilovgrad, increased just a little between 1955 and 2001 (slopes of 0.001 or less). For Podgorica, the LFC tends to increase $(<0.001)$, while the RC decreases (slope of -0.005). The RC changes at Podgorica can be separated in two different periods: it decreased most strongly between 1949 and 1980, while a further decrease between 1980 and 2004 was rather small.

\subsubsection{Photographic evidence}

Some photo-couples, which were used to estimate land use changes, clearly portray river morphology and may also be used to find evidence for changed river dynamics (Table 2).

< Table 2 approximately here> 
All the comparisons between historical and recent photographs show rivers that have become more incised and narrower; often braided rivers have changed to single channel rivers. Furthermore, the river banks are more vegetated, which is also affecting river dynamics.

\subsection{Population changes}

After grouping the population data of the different municipalities by study region, some clear tendencies appear. The Coastal municipalities especially experienced a strong growth after 1972. In the northern Mountain region of Montenegro, the population grows steadily between 1948 and 1981, but falls back after 1981, with 18\%. The largest population growth between 1948 and 2003 occurred in the central region, with $117 \%$. Particularly, the municipalities Nikšić and Podgorica in the central region experienced a strong growth, at the relative expense of the surrounding municipalities. It is most probable that this urbanization will further continue, considering the recent population tendencies of the larger cities in Montenegro (Table 3). The Coast is almost reaching the same growth rate (109\%), but this growth occurred mainly in the recent period.

\section{$<$ Table 3 approximately here>}

Most probably, the rural depopulation is not fully represented in the above data due to the fact that the spatial scale does not allow a representation of the move from rural areas to urban centres within the municipalities. For instance, in the period 1948-1981, the number of inhabitants in the municipal urban centres has grown 4.4 times (Bakić et al., 1991). These urban centres are the governmental centre of every municipality, which also bears the name of the city. These twentyone cities also provide some important facilities for the municipality.

Besides changes in absolute population numbers, there is a sectoral shift in employment: in 1981, only 5.3\% of the Montenegrin population was active in the agricultural sector, whereas this was 75.4\% in 1948 (Radović, 1981). Unfortunately, no sectoral employment data could be found for the period after 1981, but we may assume that in the recent period the agricultural population has stayed low. Reliable livestock statistics could not be found, though they would also have been interesting, as livestock acts as a direct manager of land cover.

\section{Discussion}

\subsection{Opportunities and limitations of the repeat photography methodology}

The method of photograph comparison offers a great opportunity to study landscape changes for a longer time period (Zier and Baker, 2006). By using different experts who contribute to the survey, different insights are combined and incorrect evaluations are avoided by using the best judgements.

Through the use of 48 photo-couples, it became possible to estimate the trajectory that the landscape followed, particularly the increase in woodland and the decrease of barren areas (Fig. 3 ). The amount of infrastructure increased, while agricultural land decreased. These changes mostly happened between 1931 and 1961. Unfortunately, there were no photographs of the intermediate period, so we could not define the exact moment at which most land use changes took place.

The historical photographs are not equally distributed over Montenegro, as the authors of the historical photographs generally photographed the most scenic landscapes; hence our analytical possibilities depend on their decision whether a landscape is important or not. However, the original photographers judged the landscapes by different parameters than the parameters involved in this study. They could not foresee whether a specific LUC change would take place 
in the upcoming century, an era that included several wars and particularly the Second World War as well as industrialisation and socialist transformation of the society.

By grouping the photographs in three regions, it was possible to generalize changes, as it could be expected that homogeneous regions are having a good spatial correlation concerning land characteristics and management.

\subsection{Land use changes, hydrological response and changing populations linked}

The general tendency with regard to hydrology can be observed on the pictured photographs (Table 2). It shows generally narrower rivers in 2009, visibly more incised. Both changes are characteristic of decreased sediment supply (e.g., Billi and Rinaldi, 1996; Preciso et al., 2011; Sear et al., 2003), which is in line with protection from erosion by increased vegetation cover in the catchment. Another observation is that in 2009 vegetation cover on river banks was much denser than in the early $20^{\text {th }}$ century. This could be related to (1) the fact that in the past the riparian vegetation was cleared by the local farmers for use as wood and fodder and that this is no longer carried out at the present time, and (2) colonisation of the bedrock reaches due to decreased flooding.

$<$ Figure 8 approximately here>

In the three geographical regions, some major trends have occurred (Fig. 8). In the Coastal region, the area covered by woodland increased steadily between 1910 and 2009 (Fig. 8a). The effect on the hydrology could however not be determined, as there are no rivers of which discharge is measured in this region. The population of this region increased remarkably, essentially in the touristic coastal cities. When travelling in the Coastal area, as soon as one is out of sight of the sea, a landscape similar to the hills and mountains of the central region appears, with abandoned villages and vigorously growing bushes.

In the Innerland region, woodland has increased notably, while the share of barren land has decreased (Fig. 8b). The RC of the river Morača, measured at Podgorica, has been modified. The RC has decreased strongly between 1948 and 1980, but rather slowly between 1980 and 2004. The LFC rose steadily between 1948 and 1980, but hardly increased between 1980 and 2004. This basin showed a strong response of hydrology to changes in vegetation cover. The population in the Innerland region has also increased strongly.

The wooded areas in the Mountain region increased slightly over the study period, while barren land nearly completely disappeared (Fig. 8c). The hydrological data of Pernica are used, as the upper Morača is flowing through the Mountain region. The LFC increased strongly since 1980. The population of the Mountain region increased between 1950 and 1970, but decreased strongly after that.

The industrialisation that took off in the 1950s led to wide urbanisation and abandonment of mountain farming. Despite steadily increasing population (with the notable exception of the Mountain region), the vegetation cover has increased significantly everywhere. This denser vegetation has led to higher infiltration (Coppin and Richards, 1990; Styczen and Morgan, 1995). Partitioning of this infiltration water led on one hand to deep infiltration and better low flows (Descheemaeker et al., 2009) and on the other hand to increased evapo-transpiration at the boundary layer (Styczen and Morgan, 1995), leading to slightly to strongly decreased total RCs, to which canopy interception may also have contributed (Dunne and Leopold, 1978; Zhao et al., 2010). 
In this framework, the upper Morača (Pernica and Zlatica stations) shows a deviant behaviour. LFC increased much more rapidly than that of the wider basins of Morača and Zeta. We attribute this to the fact that the wider basins are overall located on highly karstified limestone, where infiltration is high anyway, and increased vegetation contributes only slightly to infiltration and LFC. By contrast, most of the upper Morača catchment lies on silicoclastic and magmatic rocks (Karaman and Beeton, 1981; van Welden et al., 2008) where infiltration rates (hence LFC) were low under conditions of poor vegetation cover, but increased strongly with regrowing vegetation (Fig. 8c).

The increase of total RC in Pernica and Zlatica stations since 1980, on the other hand, is in contradiction with its stable or decreasing trend in the major rivers. This might be related to another factor than changes in vegetation cover, the most plausible of which is earlier snowmelt in the upper mountains that constitute a large part of the upper Morača catchment (COWI, 2010). A shift in streamflow from spring snowmelt to winter runoff (García-Ruiz et al., 2011) would lead to less sublimation and evaporation and hence larger RCs (Immerzeel et al., 2009). After 1980 , this signal would be much stronger than the abstraction by increased vegetation cover in the lower catchment.

At the downstream end, Skadar Lake where most sediments of the Morača-Zeta drainage system are trapped, is another archive of environmental changes in Montenegro and the adjacent part of Albania. It's sediments show a continuous increase in organic matter since 1963 (van Welden et al., 2008), which one may link to the observed increases in vegetation cover. Cores of sediment were taken in the Albanian part of the lake, near the outlet (van Welden et al., 2008), at a place where the waters of the Drim flow into the lake during major events (Prohaska and Isailovic, 2004). Clear changes in sediment texture in the late 1970s are attributed to the impact of dam building on the Drim (in Albania) (van Welden et al., 2008) and an apparent subsequent downcutting and wash of earlier deposited sandy material from river beds into the lake, a signal that seems to overrun the possible effect of decreased soil erosion in the catchment of the Morača.

The findings of study fit with the general background that, in the former SFR of Yugoslavia, in the period 1948-1990, large erosion control works were carried out (Blinkov et al., 2007; Zlatić, 2002a). The main goals of these works were torrential flood control, protection of settlements, water reservoir protection from sedimentation and protection of roads and railways. Various authors (Keesstra et al., 2009; Kostadinov et al., 1995) also report that as a result of erosion control and significant changes of land use, by 1990, rainfall-runoff response had significantly decreased in the former SFR of Yugoslavia and low flows increased.

\section{Conclusions}

The increase in vegetation in the $20^{\text {th }}$ century is quite remarkable in Montenegro. These changes are the most remarkable in the areas that underwent stronger human pressure, the Coastal and the Innerland regions. Changes are less striking in the Mountain areas. The largest vegetation recovery occurred between 1950 and 1980, which is also evidenced by the hydrological response. The changes in population density of the regions are of minor importance, as the increasing urbanization and abandonment of marginal agriculture is having a greater influence.

The touristic activities near the coast were not particularly studied here, but hydrological effects of poorly planned urbanisation are obvious in the field, especially in hilly areas.

The magnitude and speed of vegetation recovery in Montenegro indicates that the seemingly barren landscape is not a natural state of equilibrium but has been induced by human pressure. When this stress was released in the 1950s-1960s, vegetation has started to recover. 
Finally, the repeat photography shows the changes that may occur if hills and mountains are kept free from major interference over 50 years.. The potential for regeneration of vegetation and its impact on hydrology indicate the type of changes that may be expected in other areas of the world, if vegetation is allowed to regrow. This opens perspectives for other Mediterranean countries that still suffer from desertification, as well as for other regions in the world with a similar bio-physical setting.

\section{Acknowledgements}

For this study, we received the assistance of Prof. Dr. Miroslav Doderović and Vasilj Jovović (University of Nikšić, Department of Geography) and Prof. Dr. Luka Mitrović (Meteorological and Hydrological Institute of Podgorica). Alexandar Berkuljan (National Museum of Montenegro) enthusiastically provided an important set of historical photographs. So many people of Montenegro provided hospitality, delicious meals and free rides. Special thanks go to Father Avram (Ostrog), to Aleksandar and Bianca Bojić (Kolašin) and to Milan and Sonja Kovačević (Podgorica) and their children Ljubica, Maša and Danilo. Paolo Billi was on sabbatical at UGent when the research was carried out, and supported through the University's Special Research Fund. Koen Gillijns is thanked for contributing to the interpretation of the matched repeat photographs. Miodrag Zlatić (University of Belgrade) fostered the cooperation between the Belgian and Montenegrin teams. The useful remarks by two anonymous reviewers and editing of English language by geomorphologist R. Neil Munro are gratefully acknowledged.

\section{References}

Ager D V. 1980. The geology of Europe. McGraw-Hill, London.

Bakić R, Popović S, Radojičić B, Burić M, Kasalica S, Ivanović Z, Vukotić M. 1991. Geografija Crne Gore. Univerzitetska riječ, Nikšić.

Beguería S, Lana-Renault N, Regüés D, Nadal-Romero E, Serrano-Muela P, García-Ruiz J M. 2008. Erosion and sediment transport processes in Mediterranean mountain basins. In: P García-Navarro, E Playán (Eds.), Numerical Modelling of Hydrodynamics for Water Resources. Taylor \& Francis, London, pp. 175-187.

Billi P, Rinaldi M. 1996. Human impact on sediment yield and channel dynamics in the Arno river (central Italy). IAHS Special Publ. 245, 301-311.

Blinkov I, Trendafilov A, Andonoska B. 2007. Comparison of erosion and torrent control works in some Balkan countries, International conference 60 years Faculty of Forestry - Skopje, Ohrid, FYROM.

Bošković M, Bajković I. 2002. Waters of Montenegro. Hydrometeorological Institute of Podgorica, Podgorica.

Brandt C J, Thornes J B. 1996. Mediterranean Desertification and Land Use. Wiley, Chichester.

Bras R L. 1990. Hydrology. An Introduction to Hydrologic Science. Addison-Wesley, Cambridge.

Butzer K. 2005. Environmental history in the Mediterranean world: cross-disciplinary investigation of cause-and-effect for degradation and soil erosion. Journal of Archaeological Science 32 1773-1800.

Comber A J, Fisher P F, Wadsworth R A. 2007. Land cover: to standardise or not to standardise? Comment on 'Evolving standards in land cover characterization' by Herold et al. Journal of Land Use Science 2(4), 283 - 287.

Coppin N J, Richards I G. 1990. Use of Vegetation in Civil Engineering. Elsevier Science / Butterworth Heinemann. 
COWI. 2010. Strategic Environmental Impact Assessment for Detailed Spatial Plan for Hydro Power Projects (HPPs) on the Morača River. COWI Consortium and Norwegian Water Resources and Energy Directorate.

Descheemaeker K, Raes D, Nyssen J, Poesen J, Mitiku Haile, Deckers J. 2009. Changes in water flows and water productivity upon vegetation regeneration on degraded hillslopes in northern Ethiopia: a water balance modelling exercise. The Rangeland Journal 31, 237 249.

Dunne T, Leopold L. 1978. Water in Environmental Planning. Freeman, New York.

Fisher P F, Comber A J, Wadsworth R A. 2005. Land use and Land cover: Contradiction or Complement. In: P Fisher, D Unwin (Eds.), Re-Presenting GIS. Wiley, Chichester, pp. 85-98.

García-Ruiz J M, López-Moreno J I, Vicente-Serrano S M, Lasanta-Martínez T, Beguería S. 2011. Mediterranean water resources in a global change scenario. Earth-Science Reviews 105(3-4), 121-139.

Geeson N, Brandt C J, Thornes J B. 2002. Mediterranean Desertification: A Mosaic of Processes and Responses. Wiley, Chichester.

Geist H, Lambin E. 2006. Land-use and land-cover change: local processes and global impacts. Springer, Berlin.

Gorte B G H. 1998. Probabilistic segmentation of remotely sensed images. Ph.D thesis. Wageningen University.

Grimes A P, Latif M A, Vujadinovic-Colic J, Buskovic V. 2005. Biodiversity assessment update for Serbia and Montenegro. USAID/Serbia-Montenegro.

Grove A T, Rackham O. 2001. The Nature of Mediterranean Europe: an Ecological History. Yale University Press, New Haven and London.

Hill J, Stellmes M, Udelhoven T, Röder A, Sommer S. 2008. Mediterranean desertification and land degradation: Mapping related land use change syndromes based on satellite observations. Global and Planetary Change 64(3-4), 146-157.

HMSM. 2010. Hydrological and Meteorological Service of Montenegro, http://195.66.163.23/index.php.

Hoffman M T, Todd S W. 2010. Using Fixed-Point Photography, Field Surveys, and GIS to Monitor Environmental Change in Riemvasmaak, South Africa In: R H Webb, D E Boyer, R M Turner (Eds.), Repeat photography - methods and applications in natural sciences. Island Press, Washington DC, pp. 298-309.

Hooke J M. 2006. Human impacts on fluvial systems in the Mediterranean region. Geomorphology 79(3-4), 311-335.

Hupy J P, Schaetzl R J. 2006. Introducing "Bombturbation," A Singular Type of Soil Disturbance and Mixing. Soil Science 171(11), 823-836 810.1097/1001.ss.0000228053.0000208087.0000228019.

Immerzeel W W, Droogers P, de Jong S M, Bierkens M F P. 2009. Large-scale monitoring of snow cover and runoff simulation in Himalayan river basins using remote sensing. Remote Sensing of Environment 113(1), 40-49.

Isaaks E H, Srivastava R M. 1989. Polygon Declustering. In: E H Isaaks, R M Srivastava (Eds.), An introduction to applied geostatistics. Oxford University Press, New York, pp. 238241.

Kalnay E, Cai M. 2003. Impact of urbanization and land-use change on climate. Nature 423(6939), 528-531. 
Karaman G, Beeton A. 1981. The biota and limnology of Lake Skadar. Smithonian Institution and Univerzitet Veljko Vlahvic, Washington DC, Titograd.

Keesstra S D, van Dam O, Verstraeten G, van Huissteden J. 2009. Changing sediment dynamics due to natural reforestation in the Dragonja catchment, SW Slovenia. Catena 78, 60-71.

Kosmas C, Danalatos N, Cammeraat L H, Chabart M, Diamantopoulos J, Farand R, Gutierrez L, Jacob A, Marques H, Martinez-Fernandez J, Mizara A, Moustakas N, Nicolau J M, Oliveros C, Pinna G, Puddu R, Puigdefabregas J, Roxo M, Simao A, Stamou G, Tomasi N, Usai D, Vacca A. 1997. The effect of land use on runoff and soil erosion rates under Mediterranean conditions. CATENA 29(1), 45-59.

Kostadinov S, Marković S, Dragović N. 1995. Erosion Control Works and Their Effects on the State of Erosion and Sediment Transport in the Kalimanska Reka Watershed. In: R B Singh, M J Haigh (Eds.), Third International Symposium on Headwater Control: Sustainable Reconstruction of Highland and Headwater Region. Oxford and IBH, pp. 477-486.

Le Houérou H N. 1989. Global change: population, land use and vegetation in the Mediterranean basin by the mid-21st century. In: R Paepe, R W Fairbridge, S Jelgersma (Eds.), NATO Advanced Research Workshop on Geohydrological Management of Sea Level and Mitigation of Drought. Springer, Fuerteventura, Canary Islands, Spain, March 1-7, pp. 301-368.

Mannion A M. 2003. The environmental impact of wars and terrorism. University of Reading, Reading.

Meire E, Frankl A, Mitiku Haile, Nyssen J. 2011. Mapping the 19th century landscape in Africa Warped terrestrial photographs of North Ethiopia. Regional Environmental Change, submitted.

Montenegro Statistical Office. 2008. Statistical Yearbook 2008. Pobjeda a.d., Podgorica.

Nyssen J, Mitiku Haile, Nauds J, Munro N, Poesen J, Moeyersons J, Frankl A, Deckers J, Pankhurst R. 2009. Desertification? Northern Ethiopia re-photographed after 140 years. Science of the Total Environment 407, 2749-2755.

Nyssen J, Poesen J, Descheemaeker K, Nigussie Haregeweyn, Mitiku Haile, Moeyersons J, Frankl A, Govers G, Munro R N, Deckers J. 2008. Effects of region-wide soil and water conservation in semi-arid areas: the case of northern Ethiopia. Zeitschrift für Geomorphologie 52, 291 - 315.

Pielke R A, Marland G, Betts R A, Chase T N, Eastman J L, Niles J O, Niyogi D d S, Running S W. 2002. The influence of land-use change and landscape dynamics on the climate system: relevance to climate-change policy beyond the radiative effect of greenhouse gases. Philosophical Transactions of the Royal Society of London. Series A: Mathematical, Physical and Engineering Sciences 360, 1705-1719.

Preciso E, Salemi E, Billi P. 2011. Land use changes, torrent control works and sediment mining: effects on channel morphology and sediment flux, case study of the Reno River (Northern Italy). Hydrological Processes, submitted.

Prohaska S, Isailovic D. 2004. Water resources of the Scutari Lake basin within the territory of Montenegro, Conference on Water Observation and Information System for Decision Support. Institut de Recherche pour le Développement, Ohrid, pp. 1-6.

Radojičić B. 2008. Geografija Crne Gore, društvena osnova. Danu, Podgorica.

Radović M. 1981. Savremene društveno-ekonomske promjene u SR Crnoj Gori. In: Z Ivanović (Ed.), XI congress of Yugoslav geographers in Montenegro Geografsko društvo SR Crne Gore, Titograd, pp. 32-33. 
Radulovic V, Radulovic M. 1997. Karst of Montenegro. In: Z Stevanovic (Ed.), 100 years of hydrology in Yugoslavia. University of Belgrade, Belgrade.

Sear D A, Newson M D, Thorne C R. 2003. Guidebook of Applied Fluvial Geomorphology. R\&D Technical Report FD1914. DEFRA, London.

Spalević V. 2011. Impact of land use on runoff and soil erosion in Polimlje, Doctoral thesis. Agriculture faculty, University of Belgrade, Serbia.

Styczen M E, Morgan R P C. 1995. Engineering properties of vegetation. In: R P C Morgan, R J Rickson (Eds.), Slope Stabilization and Erosion Control. Spon, London, pp. 5-58.

Teegavarapu R S V, Chandramouli V. 2005. Improved weighting methods, determinic and stochastic data-driven models for estimation of missing precipitation records. Journal of Hydrology 312, 191-206.

Turner R M, Ochung' H A, Turner J B. 1998. Kenya's Changing Landscape. University of Arizona Press, Tucson, AZ, USA.

United Nations. 2008. World Urbanization Prospects: The 2008 Revision. United Nations, Department of Economic and Social Affairs, Population Division. United Nations Publications Board, New York.

van Welden A, Beck C, Reyss J-L, Bushati S, Koci R, Jouanne F, Mugnier J-L. 2008. The last 500 year of sedimentation in Shkodra Lake (Albania/Montenegro): paleoenvironmental evolution and potential for paleoseismicity studies. Journal of Paleolimnology 40(2), 619633.

Veldkamp A, Gams I. 1978. The polje: The problem of definition. Zeitschrift für Geomorphologie 22, 170-181.

Webb R H, Hereford R. 2010. Historical Arroyo Formation: Documentation of Magnitude and Timing of Changes Using Repeat Photography. In: R H Webb, D E Boyer, R M Turner (Eds.), Repeat photography - methods and applications in natural sciences. Island Press, Washington DC, pp. 89-104.

White S, García-Ruiz J M, Martí-Bono C, Valero B, Errea M P, Gómez-Villar A. 1997. The 1996 Biescas campsite disaster in the Central Spanish Pyrenees, and its temporal and spatial context. Hydrological Processes 11, 1797-1812.

Wraber T. 1983. Map of natural potential vegetation of SFR Yugoslavia, scale 1:1 000000. Jovan Hadži Biological Institute ZRC SAZU, Skopje.

Wyon R, Prance G. 1903. The land of the black mountain; the adventures of two Englishmen in Montenegro. Methuen, London.

Zhao F, Zhang L, Xu Z, Scott D F. 2010. Evaluation of methods for estimating the effects of vegetation change and climate variability on streamflow. Water Resour. Res. 46(3), W03505.

Zier J L, Baker W L. 2006. A century of vegetation change in the San Juan Mountains, Colorado: An analysis using repeat photography. Forest ecology and Management 228, 251-262.

Zlatić M. 2002a. Adaptation of the production to Sustainable Soil Management and its Natural and Economic Efficiency in Topčiderska River Watershed in Rakovica and Voždovac Community, 12th International Soil Conservation Organization Conference, Soil \& Water Conservation Regional Policies and Action, Vol. I, Beijing pp. 384-390.

Zlatić M. 2002b. Socio-Economic Aspects of Degradation and Soil Management for Sustainability in Mountainous Regions, Key note paper, International Year of Mountains Conference: "Natural and Socio-Economic Effects of Erosion Control in Mountainous Regions". Vrujci Spa, Belgrade pp. 497-516. 
Zlatić M, Dragovic N. 1998. Demographic-Economic Aspects of Erosion Processes and Sustainable Soil Management in Hilly-Mountainous Regions, Serbia, Fourth International Conference on Headwater Control, Merano, Italy. Balkema, Rotterdam, pp. 391-398. 
Tables

Table 1. Overview of the hydrological stations used in this study (Source: HMSM, 2010).

\begin{tabular}{llrrll}
\hline $\begin{array}{c}\text { Hydrological } \\
\text { station }\end{array}$ & River & $\begin{array}{c}\text { Catch- } \\
\text { ment } \\
\text { area } \\
\left(\mathrm{km}^{2}\right)\end{array}$ & Since & $\begin{array}{l}\text { Meteorological stations used } \\
\text { to calculate the area-weighted } \\
\text { average of yearly rainfall }\end{array}$ & Since \\
\hline $\begin{array}{l}\text { Danilovgrad } \\
\text { Pernica }\end{array}$ & Zeta & 1216 & 1948 & $\begin{array}{l}\text { Danilovgrad } \\
\text { Lijeva Rijkea, Ulice, } \\
\text { Manastir Morača, Andrijevo, }\end{array}$ & 1980 \\
& 441 & 1956 & & $\begin{array}{l}\text { Manovica Polje } \\
\text { Dratica }\end{array}$ \\
Morača & 985 & 1983 & $\begin{array}{l}\text { Lijeva Rijkea, Bioče, } \\
\text { Manastir Morača, Ulice, }\end{array}$ & 1980 \\
& & & $\begin{array}{l}\text { Dragovica Polje, Andrijevo, } \\
\text { Kupine, Pelev Brijeg, }\end{array}$ & \\
& & & & $\begin{array}{l}\text { Orahovo } \\
\text { Podgorica }\end{array}$ & 1949 \\
\hline
\end{tabular}

Table 2. Hydrogeomorphological changes observed on repeat photographs

\begin{tabular}{|c|c|c|c|}
\hline $\begin{array}{l}\text { Photo- } \\
\text { couple* }\end{array}$ & Place (year) & River & $\begin{array}{l}\text { Changed river dynamics; the situation in } 2009 \text { as compared } \\
\text { to the historical period }\end{array}$ \\
\hline $\begin{array}{l}3,4,5, \\
6\end{array}$ & $\begin{array}{l}\text { Bioče, Berane } \\
\text { (1929) }\end{array}$ & Lim & $\begin{array}{l}\text { River banks are more vegetated, \& river seems to be } \\
\text { incised and narrower. Buildings in the former flood plain. } \\
\text { See also Fig. } 6 .\end{array}$ \\
\hline $7,8,9$ & $\begin{array}{l}\text { Bioča } \\
(1910)\end{array}$ & Morača & $\begin{array}{l}\text { Hard to make conclusions, as there is a differing water } \\
\text { level on the pictures. In } 2009 \text {, more vegetation growth near } \\
\text { the river bank. On photograph 9, one branch was } \\
\text { abandoned. }\end{array}$ \\
\hline 16,17 & Dukla (1910) & Zeta & River seems to be narrower and incised. \\
\hline 20 & Kolašin (1910) & Tara & River seems to be narrower and incised \\
\hline 34 & Nikšić (1910) & Zeta & $\begin{array}{l}\text { The Zeta is incised, and part of its previous bed is } \\
\text { abandoned. }\end{array}$ \\
\hline 48 & $\begin{array}{l}\text { Manastir } \\
\text { Morača (1910) }\end{array}$ & Morača & $\begin{array}{l}\text { River bank is more vegetated; river seems to be narrower } \\
\text { and incised }\end{array}$ \\
\hline
\end{tabular}

*Numbering of the repeat photographs in the Online Supplementary Material

Note: historical photographs 37 to 44 at Rijeka Crnojevića, as well as Fig. 5, do not represent a river, but the end of a ria that is connected to Skadar Lake - hence variability in water level is related to seasonal lake fluctuation only.

Table 3. Population growth in Montenegro and its main urban centres (Source: Montenegro Statistical Office, 2008)

\begin{tabular}{llll} 
& $\begin{array}{l}\text { Inhabitants } \\
1948\end{array}$ & 2003 & $\begin{array}{l}\text { Average yearly } \\
\text { growth }\end{array}$ \\
\hline Nikšić & 6007 & 58212 & $4.2 \%$ \\
Podgorica & 26483 & 136473 & $3.0 \%$ \\
Montenegro & 377189 & 620145 & $0.9 \%$ \\
\hline
\end{tabular}


Figure captions

Figure 1. Orohydrography of Montenegro with location of the historical photographs. Heavy lines delimit the spatial units taken into consideration: the Coastal, the Innerland and the Mountain regions.

Figure 2. This photograph of the ria of Kotor shows changes that occurred in the Coastal region over a century (photo couple 23). On the foreground, as well as on the opposite side of the bay, the vegetation cover and density have increased (1910 photograph by Bjeladinovic, 2009 photograph (C) Jeroen Van den Branden). Though the repeat photographs were presented to the correspondents in black \& white, as were the historical photographs, in this paper, we present the repeat photographs in colour, in order to allow the reader to fully apprehend the type of landscapes that has been studied.

Figure 3. Average land use distribution in Montenegro throughout the $20^{\text {th }}$ century, based on interpretation of terrestrial photographs (number indicated in brackets along the y-axis). On two of the 48 interpreted photographs, two different parts, separated by a ria, were interpreted separately, leading to a total of 50 interpretations. The broken line separates the classes with woody vegetation from the others. Note that the photographs of the period 1925-1931 have a high proportion of agricultural landscapes.

Figure 4. Changes to average land use distribution as derived from repeat photography for the (a) Coastal, (b) Innerland and (c) Mountain regions of Montenegro.

Figure 5. The hills around Skadar Lake show a slight increase in vegetation between 1910 (upper photo) when pastoral activities were a major occupation and 1969 (middle photograph). The effect of decreasing pressure on the land in the 1950s and 1960s was not yet clear in 1969 as vegetation needed time to regrow. By 2009 (lower photograph), the vegetation regrowth had become much more visible. Note that the water body and the floating plants were not considered in the analysis. Area occupied by woody vegetation was estimated by the correspondents at $46 \%$ in 1910, 48\% in 1965 and 77\% in 2009 (1910 photograph by Rudolf Mosinger (c) National Museum of Montenegro, 1965 photograph (C) Melis http://www.panoramio.com/photo/683711, 2009 photograph (C Jeroen Van den Branden).

Figure 6. Valley of Lim R. at Bioča near Berane (Mountain region). There was more woody vegetation and less cropland and pasture in 2009 as compared to 1929. The number of houses had increased but land use was less intense, which is related to the fact that most inhabitants work in the nearby city of Berane. Hay heaps in the centre of the 2009 photograph and standing maize at right evidence that agricultural activities were ongoing (1929 photograph anonymous, 2009 photograph (C) Jeroen Van den Branden).

Figure 7. Changes in meteorological and hydrological parameters for 4 river basins in Montenegro since the middle of the $20^{\text {th }}$ century: (a) average yearly rainfall, (b) yearly runoff coefficient, and (c) seasonal low flow coefficient. Linear trend lines have been drawn and corresponding equations are given with the aim of representing slope angle of the tendencies. 
Figure 8. Comparisons of land use and cover, river runoff coefficients and total population in the (a) Coastal, (b) Innerland, and (c) Mountain regions of Montenegro. (LUC data from this study; hydrological information through interpretation of data provided by (HMSM, 2010); population data from Montenegro Statistical Office, 2008). 
Figures

Figure 1.

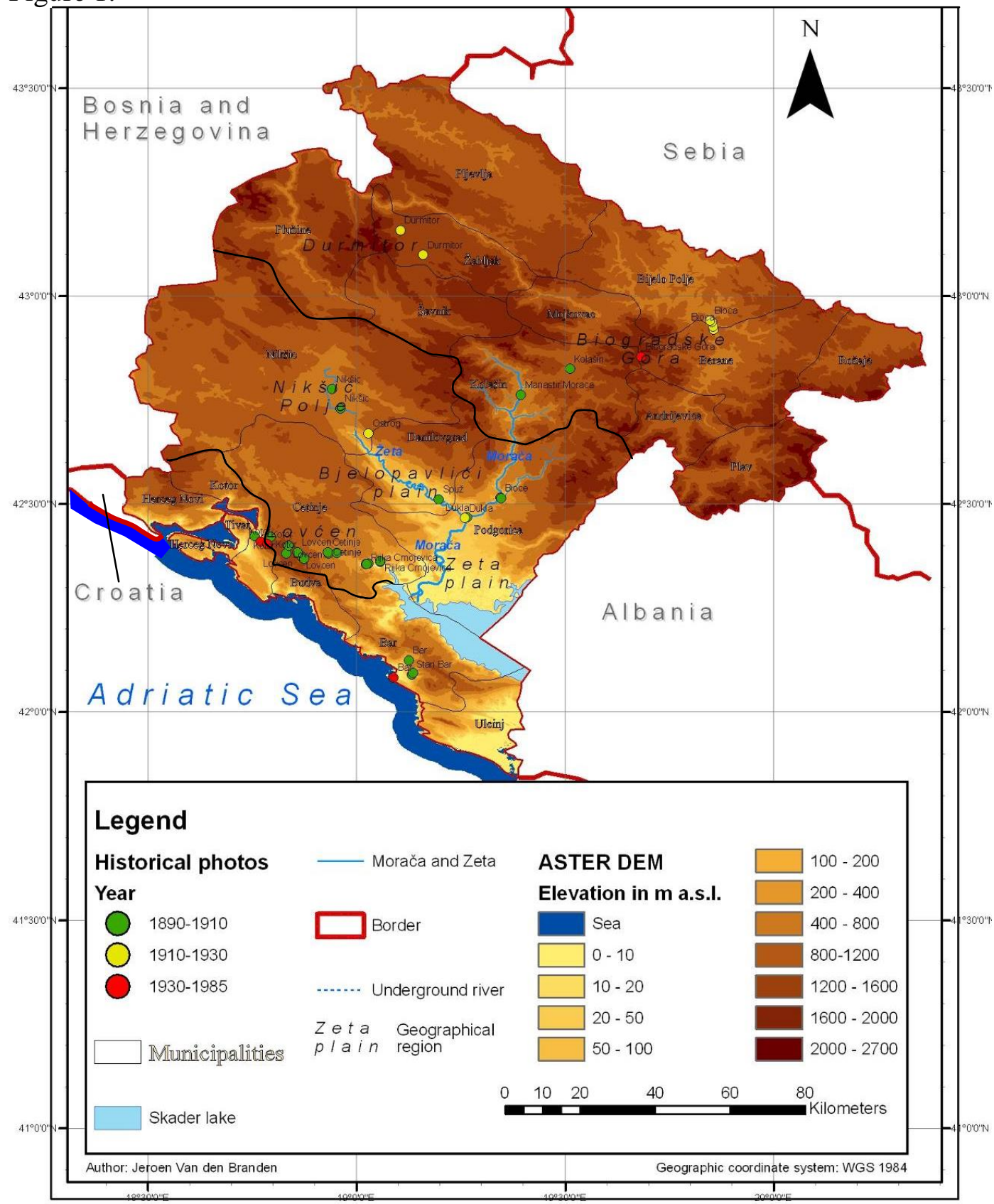


Figure 2.
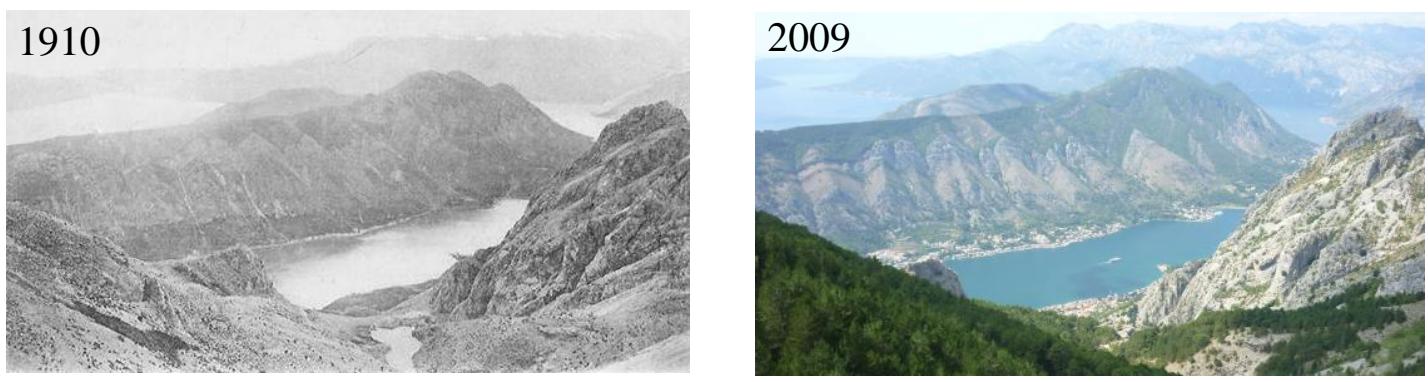

Figure 3.

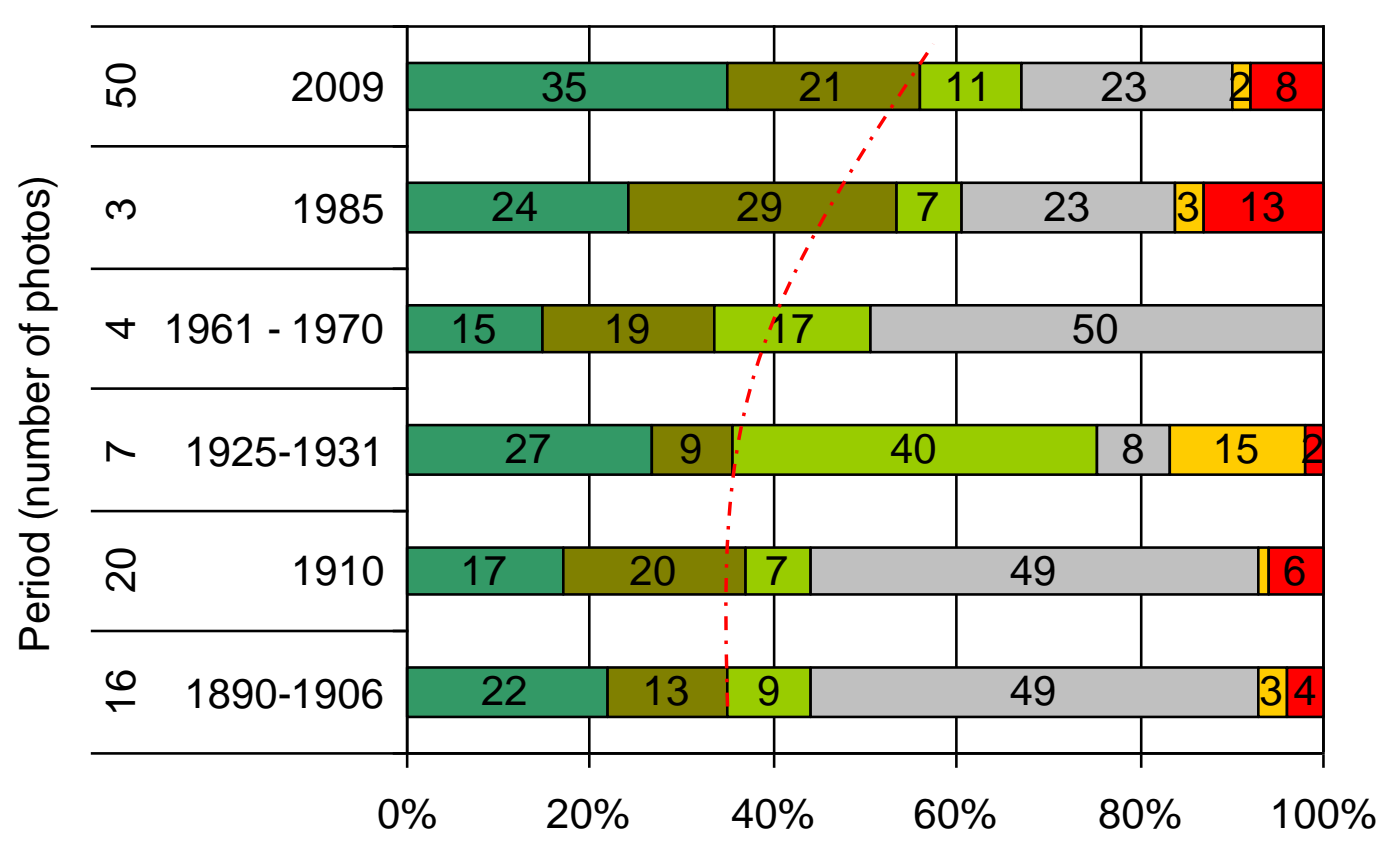

$\square$ Forest $\square$ Shrubland $\square$ Meadow $\square$ Barren $\square$ Farmland $\square$ Infrastructure 
Figure 4.
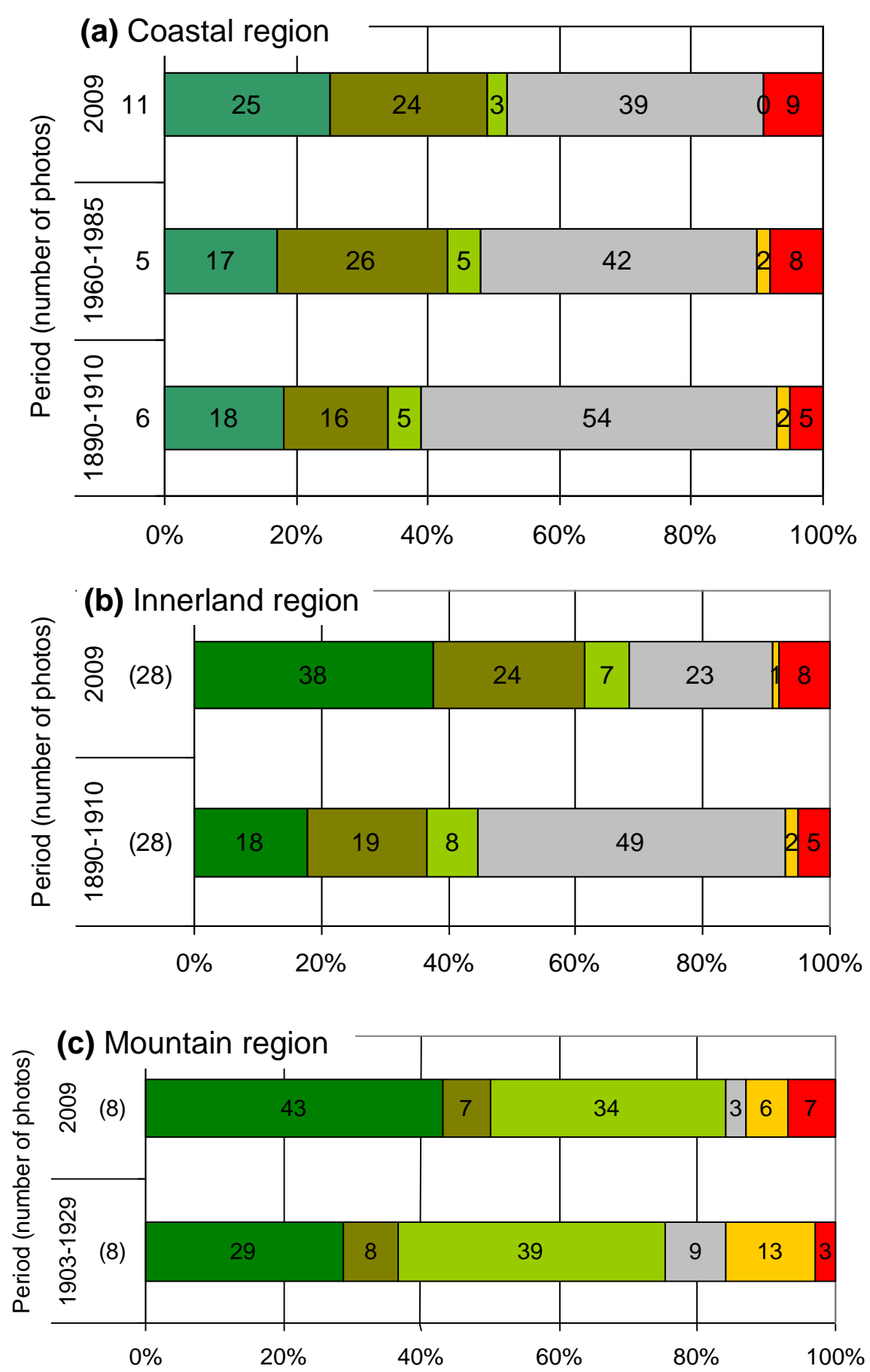

$\square$ Forest $\square$ Shrubland $\square$ Meadow $\square$ Barren $\square$ Farmland $\square$ Infrastructure 
Figure 5.

1910
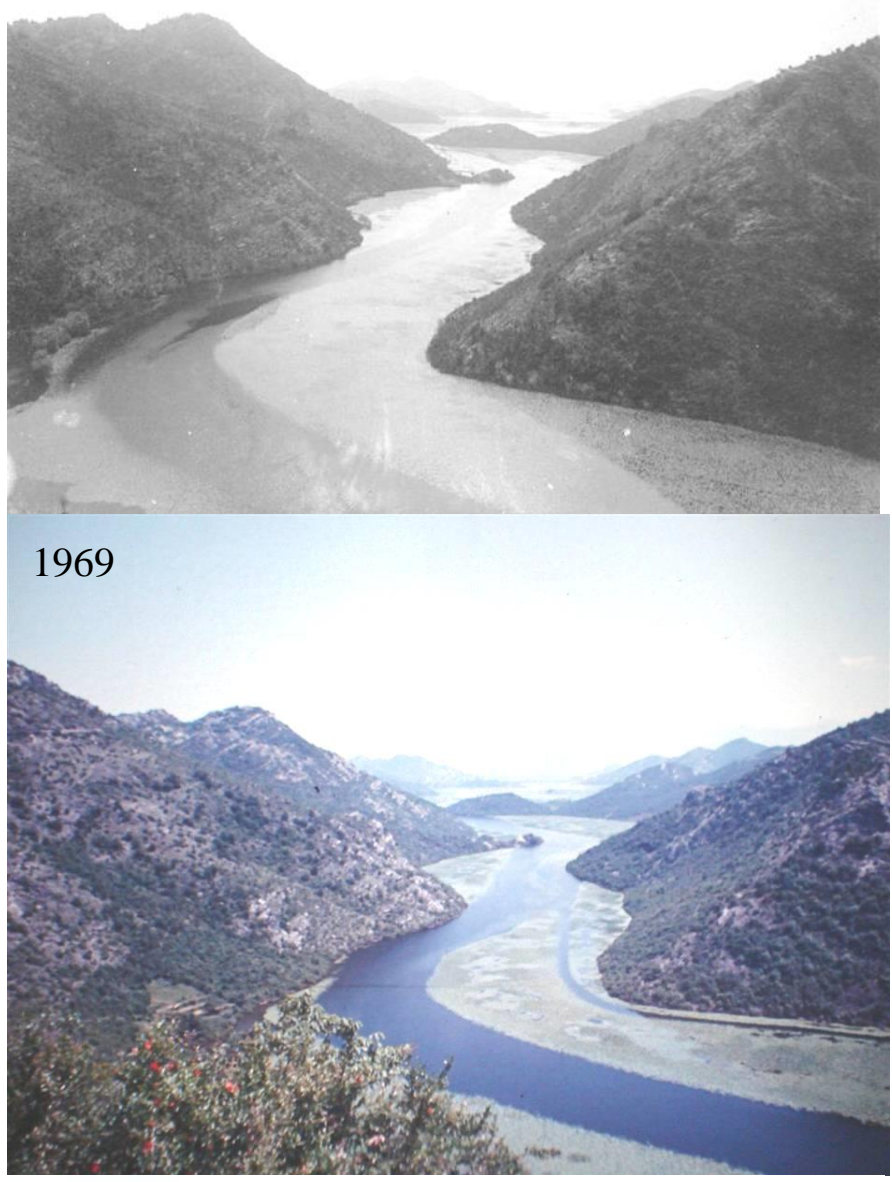

2009

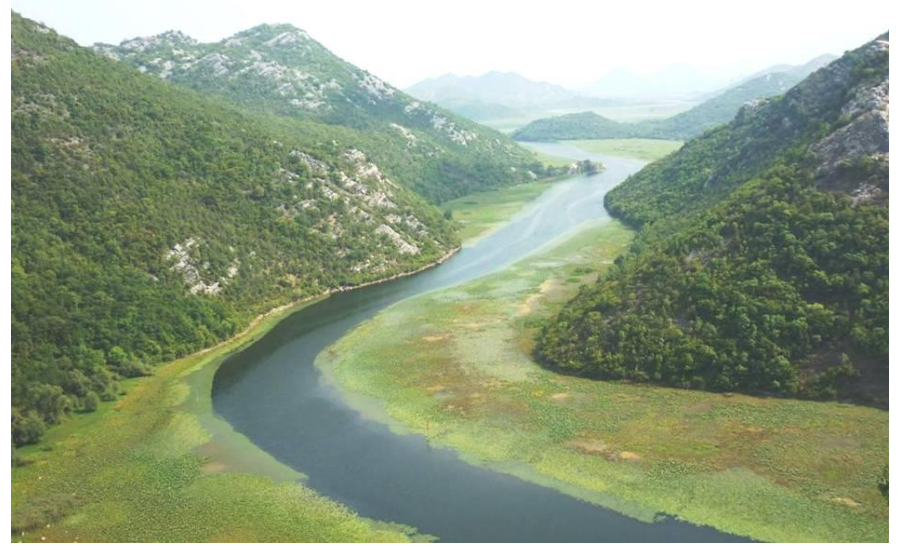


Figure 6.
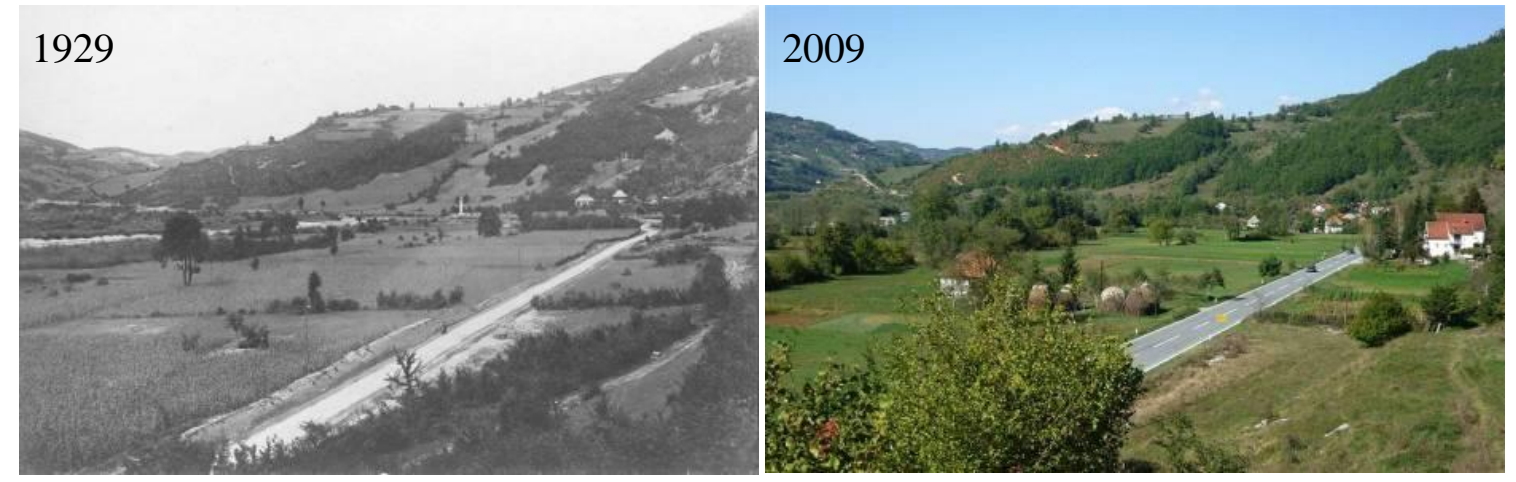
Figure 7.
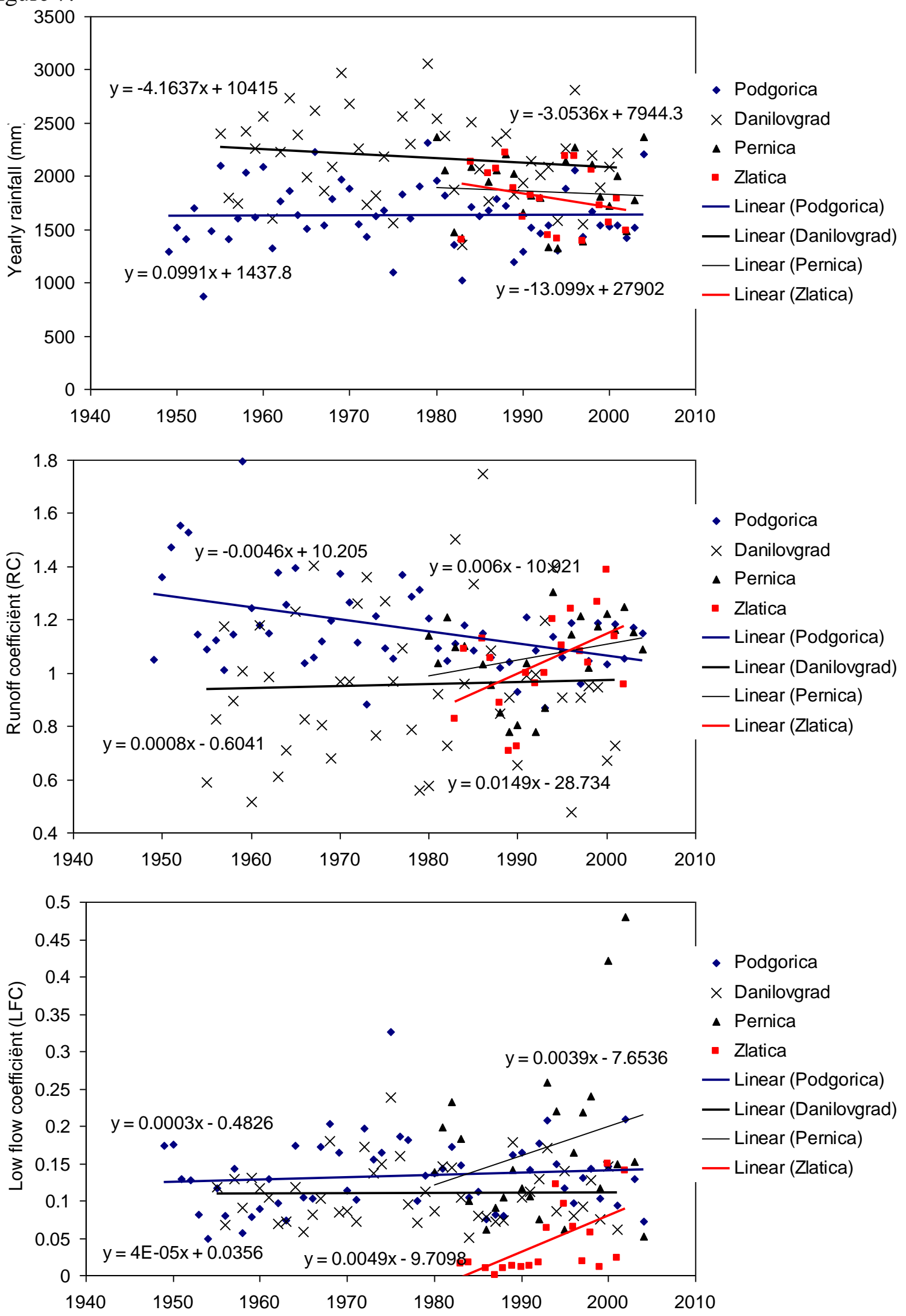
Figure 8.

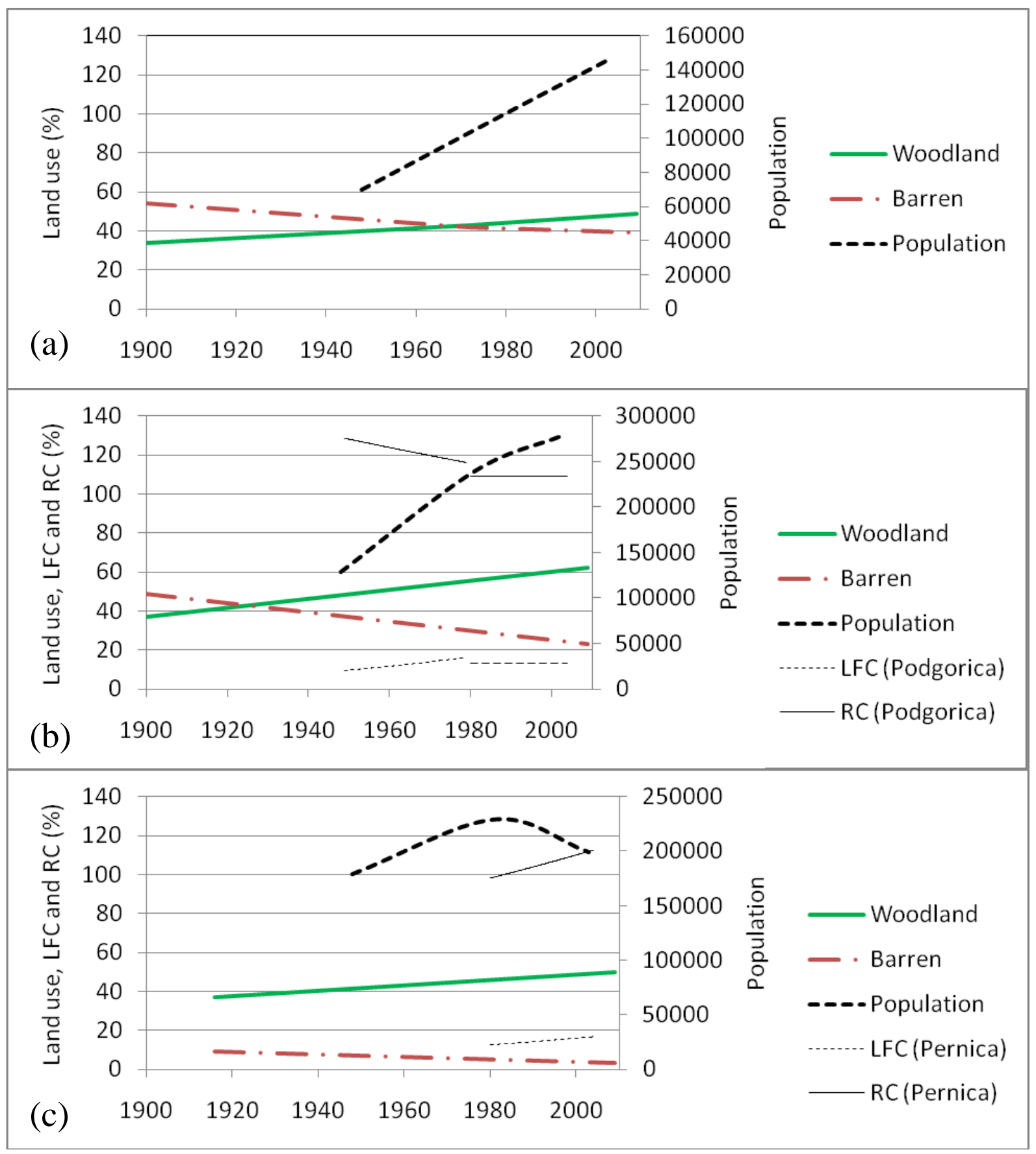

